Volume VII - Article 1

\title{
Flying The Friendly Skies May Not be So Friendly In OUTER SPACE: InTERnational and Domestic Law Leaves United States' Citizen Space Tourists Without a Remedy FOR INJURY CAUSED BY GOVERNMENT SPACE DEBRIS
}

\author{
Marla Stayduhar* \\ Fall 2006 \\ Copyright (C) University of Pittsburgh School of Law \\ Journal of Technology Law and Policy
}

\section{Introduction}

"Ladies and Gentlemen, we would like to welcome you to the moon. Please keep your seat belt fastened until the pilot completely stops at the gate. If this is your final destination, please collect your bags at baggage claim D. If you are headed on to Mars, your bags will be checked through to your final destination."

These words may sound funny now, but the possibility of them becoming a reality is not as far-fetched as it might seem. On September 18, 2006, Anousheh Ansari, a United States citizen of Iranian origin, became the fourth space tourist and the first female civilian to enter outer space. ${ }^{1}$ She also became the first astronaut to keep a space blog of her experiences to which readers could post a response. ${ }^{2}$ Shortly before Ms. Ansari's adventure, on October 1, 2005, Gregory Olsen, scientist and entrepreneur, was the third paying civilian space tourist, and took flight on a Russian shuttle. ${ }^{3}$ Although his trip cost $\$ 20$ million, ${ }^{4}$ it is not unforeseeable that

\footnotetext{
* University of Pittsburgh School of Law, J.D. expected 2007.

${ }^{1}$ Ryan Chilcote, Female Space Tourist Blasts Off, CNN.COM, Sept. 18, 2006, http://www.cnn.com/2006/TECH/space/09/18/space.female.tourist/index.html; Sara Goudarzi, Interview with Anousheh Ansari, the First Female Space Tourist, SPACE.COM, Sept. 15, 2006, http://www.space.com/missionlaunches/060915_ansari_qna.html.

${ }^{2}$ Anousheh Ansari Space Blog, http://spaceblog.xprize.org/; http://www.space.com/ missionlaunches/060915_ansari_qna.html (last visited Nov. 5, 2006).

${ }^{3}$ Crew and Tourist Head into Space, N.Y. TIMES, Oct. 2, 2005, at 31; Mike Eckel, Third Space Tourist Lifts off to 'Help Mankind', INDEP. ON SundAY, Oct. 2, 2005, at 19; Space Tourist Calls Flight “Awe-Inspiring”, CNN.COM, Oct. 17, 2005, http://www.cnn.com/2005/TECH/space/10/17/olsen/index.html.
} 
ordinary citizens will soon be able to take a short trip around the moon or visit a space resort. It has been estimated that space tourism has the potential to generate $\$ 10$ billion to $\$ 20$ billion in income in the next few decades. ${ }^{5}$ Counting on that projection, Virgin Galactic, founded by Richard Branson (the well-known billionaire adventurer ${ }^{6}$ ), recently reached an agreement with the State of New Mexico to build a space port on state land. ${ }^{7}$ Moreover, recent batches of space vehicle competitions and exhibits have piqued greater interest in space tourism for adventurers, scientists, travel agents and government officials alike. ${ }^{8}$

This potential increase of private citizens and vehicles in space runs the enhanced risk of damage, injury or death to space tourists due to collision with space debris. There is, literally, tons of junk orbiting around the earth. This debris travels at such great speeds that an object less than a centimeter in size can cause noticeable damage. Given this, it is not hard to imagine an old inoperable satellite, or even a piece of a satellite, crashing into a tourist's space craft and causing grave damage or injury.

The United States' government completely controls the domestic space industry through legislation and about half of the debris in space was generated by the United States, with the rest being generated by foreign governments, mainly Russia. $^{9}$ But, ultimately, these governments cannot be held responsible for damage to private citizens in space caused by this debris.

\footnotetext{
${ }^{4}$ Crew and Tourist Head into Space, supra note 3, at 31; Eckel, supra note 3, at 19; Space Tourist Calls Flight

“Awe-Inspiring”, supra note 3.

5 Daniel O’Neil, et Al. General Public Space Travel and Tourism (1998), http://www.spacefuture.com/archive/general_public_space_travel_and_tourism.shtml\#National.

${ }^{6}$ Virgin.com, Who's Richard Branson, http://www.virgin.com/aboutvirgin/allaboutvirgin/ whosrichardbranson (last visited Nov. 5, 2006); Steve Pyke, The Gonzo Way of Branding, FAST COMPANY.COM, Oct. 2004, http://www.fastcompany.com/magazine/87/branson.html.

${ }^{7}$ Virgingalactic.com, Virgin Galactic and New Mexico Announce Spaceport Agreement, http://www.virgingalactic.com (last visited Nov. 5, 2006).

${ }^{8}$ U.S. Team Bids to Win Space Prize, CNN.COM, Sept. 30, 2004, http://www.cnn.com/2004/TECH/09/28/spaceshipone/index.html; John Schwartz, Private Company Plans \$100 Million Tour Around the Moon, N.Y. TIMES, Aug. 10, 2005, at A1; See Molly K. Macauley, Flying in the Face of Uncertainty: Human Risk in Space Activities, 6 CHI. J. INT'L. L. 131, 137-38 (2005).

${ }^{9}$ HowArd A. BAKER, SPACE DeBris: LeGAl AND POLICY IMPLiCATIONS 3 (1989).
} 
International treaties do not provide a proper remedy ${ }^{10}$, and there is no indication that the U.S. courts will have jurisdiction over a tort claim that occurred in outer space. ${ }^{11}$ In addition, current U.S. legislation virtually shields the government from paying damages by requiring private space operators to waive liability on the part of the government. ${ }^{12}$

Due to the likelihood of private United States citizens visiting space in the future, international and domestic law must be more fully developed to encompass the type of claims that will eventually need to be addressed. A forum must be available to hold negligent or culpable government parties accountable and to compensate those that have suffered losses.

\section{Space debris presents grave risks to private citizens traveling in space.}

One of the greatest threats facing human activities in outer space is space debris. ${ }^{13}$ During the beginnings of space exploration, space "was considered empty and free for unlimited use, but now it becomes more and more populated by functioning objects and, unfortunately, by 'space garbage' which is known as space debris."14 Since the consequences of collision with even a small piece of debris could be devastating, there must be provisions to hold those responsible for the continued existence of the debris. In order to understand the need for accountability, an examination of the types and amounts of space debris is required.

\footnotetext{
${ }^{10}$ See Convention on International Liability for Damage Caused by Space Objects, Mar. 29, 1972, 24 U.S.T. 2389, 961 U.N.T.S. 187 [hereinafter Liability Convention].

${ }^{11}$ See James A. Beckman, Citizens Without a Forum: The Lack of an Appropriate and Consistent Remedy for United States Citizens Injured or Killed as the Result of Activity Above the Territorial Air Space, 22 B.C. INT'L \& COMP. L. REV. 249 (1999)(getting jurisdiction over federal govt. in U.S.); Lauren S.-B. Bornemann, This is Ground Control to Major Tom... Your Wife Would Like to Sue But There's Nothing We Can Do...the Unlikelihood that the FTCA Waives Sovereign Immunity for Torts Committed by United States Employees in Outer Space: A Call For Preemptive Legislation, 63 J. AIR L. \& CoM. 517 (1998).

12 Commercial Space Launch Activities Act (CSLA), 49 U.S.C.A. $\$ 70112$ (Supp. 2006).

${ }^{13}$ BAKER, supra note 9 , at 1.

${ }^{14}$ NANDASIRI JASENTULIYANA, INTERNATIONAL SPACE LAW AND THE UNITED NATIONS 321 (1999); NANDASIRI JASENTULIYANA, INTERNATIONAL SPACE LAW AND THE UNITED NATIONS 321 (1999); Martin Sieff, US Charts Junkyard In The Heavens, SPACEWAR, May 24, 2005, http://www.spacewar.com/news/debris-05e.html ("In less than half a century since the launch of the first man-made orbiting satellite - the Soviet Union's Sputnik I in 1957 humanity has not yet turned the near heavens into hell, but it certainly has transformed it into a junkyard.").
} 
Space debris is a popular term, not a legal one, ${ }^{15}$ and there is no international space law that has defined space debris. ${ }^{16}$ However, there have been many characterizations of what constitutes debris and some general consensus on the matter.

Space debris is mainly junk that has been left in space as a by-product of space missions and space activities. Scholars have divided space debris into four categories: inactive payloads, operational debris, fragmentation debris and micro-particulate matter. Inactive payloads are former active objects that "can no longer be controlled by their operators." 17 Inactive payloads are composed mainly of inactive satellites and space probes. ${ }^{18}$ Operational payloads are objects, associated with space activities, which remained in space. ${ }^{19}$ Such objects could be launch hardware, rocket bodies, separation hardware and objects dropped in space by astronauts. ${ }^{20}$ Debris may also be fragments that have been produced when space objects break up due to explosions, collisions and other possible unknown events. ${ }^{21}$ Space debris can even be microparticulate matter consisting of particles, gases and spaceglow ${ }^{22}$ created from rocket motors and surfaces of orbiting spacecraft. ${ }^{23}$ Space debris can be as large as a rocket or as small as a chip of paint.

However, the origination of debris is not the only important factor. In recent years, advances in space technology and exploration have greatly increased the number of objects and

\footnotetext{
${ }^{15}$ NATHAN C. GOLDMAN, AmERICAN SPACE LAW: INTERNATIONAL AND DOMESTIC 75 (1st ed. 1988).

${ }^{16}$ CARl Q. Christol, Space LaW: Past, Present, AND Future 306 (1991).

${ }^{17}$ BAKER, supra note 9 , at 4.

${ }^{18} I d$.

${ }^{19} I d$.

${ }^{20} \mathrm{Id}$.

${ }^{21} I d$.

Spaceglow is not well understood by scientists. What is known is that a continuous glow exists [around orbiters] during passive operation conditions and thruster firings. Recent studies indicate that spaceglow depends on the energy transfer to and the subsequent desorption of adsorbed species such as nitrogen compounds, particularly nitrogen dioxide. Id. at 9.

${ }^{23}$ BAKER, supra note 9, at 9 .
} 
pieces of debris in space. ${ }^{24}$ The National Aeronautics and Space Administration (NASA)

recently estimated that there are approximately 11,000 pieces of debris in space that are larger than 10 centimeters in diameter. ${ }^{25}$ This estimate does not include the hundreds of thousands of objects in space that are smaller than 10 centimeters. ${ }^{26}$ This number will only continue to grow as the fields of space exploration, tourism and commercialism expand.

One significant problem concerning this growth of debris is the "cascade effect." ${ }^{27}$ This phenomenon involves the idea that space debris will collide with each other, break apart, and form multiple new pieces of debris. ${ }^{28}$ In this manner, even if new space debris was not created, the existing debris would divide and multiply in a self-perpetuating fashion.

If the number of objects in space continues to increase and there is a corresponding influx in the number of private citizens in space, the likelihood of collision between a space vehicle and piece of debris will only become more likely. There have been numerous documented instances of collision with space debris since the beginning stages of space exploration. ${ }^{29}$ And the risk of real injury is actually quite serious when one considers the speeds at which debris is traveling through space. ${ }^{30}$ "With speeds averaging $10 \mathrm{~km} / \mathrm{second}$ (more than 35,000 km/hour), a 0.5 millimeter chip of paint could puncture a standard spacesuit, killing an astronaut engaged in

\footnotetext{
${ }^{24}$ JASENTULIYANA, supra note 14 , at 321.

${ }^{25}$ NASA Orbital Debris Program Office, Orbital Debris Frequently Asked Questions, http://orbitaldebris.jsc.nasa.gov/faqs.html\#16 (last visited Oct. 18, 2006).

${ }^{26}$ Sieff, supra note 14, at http://www.spacewar.com/news/debris-05e.html (“ 'Space Command only tracks objects larger than a baseball,' Theresa Hitchens, director of the Center for Defense Information in Washington, told United Press International. 'But there are between 100,000 and 200,000 pieces of space debris it doesn't track between the size of a baseball and a marble - and there are literally millions of smaller bios of debris than that.' ").

${ }^{27}$ BAKER, supra note 9, at 13 .

${ }^{28} \mathrm{Id}$.

${ }^{29}$ See BAKER, supra note 9, at 11; Jennifer M. Seymour, Note, Containing the Cosmic Crisis: A Proposal for Curbing the Perils of Space Debris, 10 Geo. Int'l. Envtl. L. Rev. 891, 896 (1998) ("[The] U.S. General Accounting Office has reported that in eighteen flights of the U.S. space shuttle, NASA found damage to twenty-seven shuttle windows."); Sieff, supra note 14 ("In 1999, the Space Shuttle Discovery landed with evidence of 64 impacts on its body. At least 10 of them, NASA concluded, were caused by such debris, although the objects in question were small.").

${ }^{30}$ BAKER, supra note 9, at 10; NASA Orbital Debris Program Office, supra note 25.
} 
extravehicular activity."31 "Space Shuttle windscreens have been damaged by flecks of paint as small as $0.3 \mathrm{~mm}$ in size traveling at a mere $14,400 \mathrm{~km} /$ hour. The fastest debris, at 50,000

$\mathrm{km} /$ hour, is traveling about 17 times faster than a machine gun bullet."32 Realizing the potential dangers posed by space debris, some space agencies are designing aircraft that will be able to detect and analyze damage to the craft caused by the impact of debris. ${ }^{33}$

Since space debris presents an increasingly hazardous and dangerous problem to the exploration and utilization of outer space, proper laws need to be in place to protect private citizens that participate in space activities. The current international law does not reflect an adequate remedy for injury or loss to private citizens resulting from space debris left by governments or governmental agencies.

\section{Current international law does not fully address issues of liability to a private U.S. citizen for damage caused by space debris.}

There are several international treaties concerning the use and exploration of outer space. However, these treaties pose several problems by failing to adequately define the parameters of state actor liability for damage caused by space debris.

The first United Nations treaty relevant to the issue of space debris is the Outer Space Treaty. ${ }^{34}$ Ratified in 1967 , the Treaty holds states liable for damage to another state or its citizens caused by the launching of a space object. ${ }^{35}$ This treaty poses several problems when examining the extent of liability for space debris.

\footnotetext{
${ }^{31}$ BAKER, supra note 9, at 10.

${ }^{32}$ European Space Agency, Space Debris Spotlight, http://www.esa.int/esaCP/SEMHDJXJD1E_ FeatureWeek_0.html (last visited March 31, 2005).

${ }^{33}$ Ant Logic $\bar{M}$ akes Space Sense, NEW SCIENTIST, September 12, 2005, at 25 (CSRIO and NASA teaming up to develop spacecraft skin that will assess the severity of any damage it suffers from space debris).

${ }^{34}$ Treaty on Principles Governing the Activities of States in the Exploration and Use of Outer Space, Including the Moon and Other Celestial Bodies, Jan. 27, 1967, 18 U.S.T. 2410, 610 U.N.T.S. 205 [hereinafter Outer Space Treaty].
} 
One dilemma which has developed from the treaty is the definition of an "object or its component parts. ${ }^{\not 6}$ By failing to define what a space object is, the treaty left open the possibility that refuse left in space may not actually constitute a space object. ${ }^{37}$ A second problem associated with the Outer Space Treaty is that it provides no definition as to what extent states are liable for damage caused by their space objects: ${ }^{38}$

The wording was purposely left very brief and simple because any additional details might have dealt too rapidly with problems which had not yet been settled. For instance, the parties used the term internationally liable because they could not agree on specific terms for absolute liability. The issue was left for resolution by future international agreements ... ${ }^{39}$

However, this issue was not significantly resolved in the next major treaty concerning international liability. ${ }^{40}$ The International Convention on Liability, ratified in 1972, holds a launching state absolutely liable for damage caused on the surface of the earth, and liable based on fault for damages caused elsewhere than on Earth (i.e. outer space). ${ }^{41}$ "However, there is no definition of fault set forth in the Convention itself, nor is a standard of care set forth or

Each State Party to the Treaty that launches or procures the launching of an object into outer space, including the Moon and other celestial bodies, and each State Party from whose territory or facility an object is launched, is internationally liable for damage to another State Party to the Treaty or to its natural or juridical persons by such object or its component parts on the Earth, in air space or in outer space, including the Moon and other celestial bodies. Id. art. VII.

${ }^{36} I d$.

${ }^{37}$ BAKER, supra note 9, at 61-65.

${ }^{38}$ Outer Space Treaty, supra note 34, art. VII; Van C. Ernest, Note, Third Party Liability of the Private Space Industry: To Pay What No One Has Paid Before, 41 CASE W. RES. 503, 519 (1991).

${ }^{39}$ Ernest, supra note 38, at 519.

${ }^{40}$ Liability Convention, supra note 10.

41 "A launching state shall be absolutely liable to pay compensation for damage caused by its space object on the surface of the Earth or to aircraft in flight." Liability Convention, supra note 10, art. II.

In the event of damage being caused elsewhere than on the surface of the Earth to a space object of one launching state or to persons or property on board such a space object by a space object of another launching State, the latter shall be liable only if the damage is due to its fault or the fault of persons for whom it is responsible. Id. art. III. 
guidelines for establishing negligence." ${ }^{42}$ The Liability Convention does not establish any positive duty for member states to remove or mitigate the debris left in space. ${ }^{43}$

In addition to failing to define fault, the Liability Convention once again left open the definition of space object. ${ }^{44}$ The given definition, which now includes space object components and launch vehicles, is generally seen as an expanded definition of that provided in the Outer Space Treaty. ${ }^{45}$ However, the Liability Convention failed to define component parts. ${ }^{46}$ Some scholars have agreed that term space object includes operational debris, but excludes inactive satellites, fragmentation debris, micro-particulate matter and litter. ${ }^{47}$ These latter types of debris are considered to currently pose the greatest threat to active space objects. ${ }^{48}$ The question remains as to whether these most dangerous types of debris are covered under the Treaty as space objects, or if the Liability Convention fails to even address damage caused by debris.

These criticisms of the space treaties have important implications for private citizens that may be injured by space debris on a trip to the moon. Even if an offending piece of debris could be classified as a space object under the Liability Convention, there is no method to determine fault. Considering that most debris is less than the size of a baseball, there most likely would be no way to identify to which state the refuse belonged. If for some reason the debris could be identified and assigned an owner, there is no standard of care established to define fault. Under the treaties, there is no positive duty to remove or mitigate the effects of debris. The Liability for Damages Convention contains no provisions for holding member states liable for failing to

\footnotetext{
42 BAKER, supra note 9, at 80; CHRISTOL, supra note 16, at 230; JASENTULIYANA, supra note 14 , at 326.

43 JASENTULIYANA, supra note 14, at 207.

${ }^{44}$ Liability Convention, supra note 10, art. I(d) ("The term "space object" includes component parts of a space object as well as its launch vehicle and parts thereof.").

45 JASENTULIYANA, supra note 14 , at 324 .

${ }^{46} I d$.

${ }^{47}$ BAKER, supra note 9 , at 80.

48 JASENTULIYANA, supra note 14, at 325.
} 
remove debris from space caused by their space launch activities, nor for failing to mitigate the effects of junk left in space.

Assuming that space debris is considered a space object and that fault could be assigned, the remedies available under the treaties for a private citizen are limited. ${ }^{49}$ Only member states may take action against the state at fault. ${ }^{50}$ "Initially the claim must be presented formally by the government of the victim through diplomatic channels to the allegedly liable launching state or states." ${ }^{, 1}$ What follows is a complicated system of political negotiation and claims commissions. $^{52}$ If these methods produce an amount of compensation to be awarded to a party, it is then left to the parties to honor the agreement. "[The] greatest failing of the [Liability Convention] is the nonbinding nature of the award: The decision of the Commission shall be final and binding if the parties have so agreed; otherwise, the Commission shall render a final and recommendatory award, which the parties shall consider in good faith.",53 "In the absence of an agreement establishing binding procedures for the field of space law, it is likely that most national governments will continue to resolve their disputes through diplomacy." 54 This does not leave private citizens involved in commercial space activities with much hope of receiving compensation for damage or loss from other member states under the Convention.

The dispute resolution system of the Liability Convention has only been put to the test on one occasion, and it involved a dispute between two member states, not between a private party

\footnotetext{
${ }^{49}$ See Liability Convention, supra note 10 , art. VIII.

${ }^{50} \mathrm{Id}$.

${ }^{51}$ GOLDMAN, supra note 15 , at 81 .

${ }^{52}$ Liability Convention, supra note 10, arts. XI-XX; GOLDMAN, supra note 15, at 82.

${ }^{53}$ GOLDMAN, supra note 15 , at 83.

${ }^{54}$ Wayne White, The Legal Regime for Private Activities in Outer Space, presented at Space: The Free Market Frontier, Mar. 15 2001, http://www.spacefuture.com/archive/the_legal_regime_for_private_activities_ in_outer_space.shtml.
} 
and a member state. In January 1978, COSMOS 954, a Soviet nuclear powered satellite crashed into northern Canada. ${ }^{55}$ Canada presented a claim to the Soviet Union, based on the Liability Convention and international law, for approximately $\$ 6.94$ million dollars for compensation for the cost of cleanup following the crash. ${ }^{56}$ The Soviet Union refused to pay that amount claiming that Canada did not actually suffer any damage and had spent excessive amounts to restore the environment where the satellite landed. ${ }^{57}$ The conflict between these countries was finally resolved mainly through diplomatic circumvention of the Liability Convention and the Soviet Union paid Canada approximately $\$ 3$ million dollars. ${ }^{58}$

The COSMOS 954 incident raised another weakness in the Liability Convention - - the definition of damages is not fully defined. ${ }^{59}$ The incident also illustrated the difficulty in negotiating and enforcing compensation between two member states. Furthermore, this event left open the application of the Liability Convention in the future between member states and offers no guidance as to the application if a private party were injured.

\section{Suits by private United States citizens for damages caused by space debris will not be successful against foreign nations.}

Although the implications of the Liability Convention remain questionable due to its vague terminology and infrequent application, the Convention does not prevent injured plaintiffs from seeking redress from the judicial system of their home country. ${ }^{60}$ However, in the case of damage caused by objects left in space by foreign countries, a United States citizen will most likely be unable to gain jurisdiction over the foreign nation in order to bring suit against them.

\footnotetext{
${ }^{55}$ BAKER, supra note 9, at 7; CHRISTOL, supra note 16, at 206; Ernest, supra note 38, at 524-526.

${ }^{56}$ Ernest, supra note 38, at 525.

${ }^{57} \mathrm{Id}$.

${ }^{58} I d$.

${ }^{59} I d$.

60 "Presentation of a claim to a launching State for compensation for damage under this Convention shall not require the prior exhaustion of any local remedies which may be available to a claimant State or to natural or juridical persons it represents." Liability Convention, supra note 10, art. XI.
} 
The Foreign Sovereign Immunities Act (FSIA) affords the only basis for obtaining jurisdiction over a foreign country in the United States judicial system. ${ }^{61}$ Enacted in 1976, "the FSIA establishes a framework for determining whether any United States court may exercise jurisdiction over any particular case." ${ }^{, 62}$ According to the Act, foreign states are absolutely immune from the jurisdiction of United States' courts, unless one of the statutorily defined exceptions applies. ${ }^{63}$ Thus, a United States citizen is barred from suing a foreign state in the United States' judicial system for injuries suffered, as the result of that state's activities, unless the injured party satisfies one of the exceptions in the Act. ${ }^{64}$

The FSIA outlines generally a list of seven (7) possible exceptions to the foreign sovereign immunity rule. ${ }^{65}$ Under these exceptions a United States citizen would be able to gain jurisdiction over the government of a foreign nation in the United States. ${ }^{66}$ The exceptions are as follows: 1) in an in action in which the foreign state has waived immunity; ${ }^{67} 2$ ) in an action based on commercial activity carried on in the United States by the foreign state, carried on in the United States in connection with a commercial activity of the foreign state elsewhere, or in connection with a commercial activity of the foreign state not in the United States, but which has a direct effect in the United States; ${ }^{68} 3$ ) in an action "in which property rights are taken in violation of international law" and in which the property is in the United States "in connection with a commercial activity carried on by the foreign" nation, or the property is owned by the

\footnotetext{
${ }^{61}$ Argentine Republic v. Amerada Hess Shipping Corp., 488 U.S. 428, 434 (1989) ("We think that the text and structure of the FSIA demonstrates Congress' intention that the FSIA be the sole basis for obtaining jurisdiction over a foreign state in our court.").

${ }^{62}$ Beckman, supra note 11 , at 265.

${ }^{63}$ Foreign Sovereign Immunities Act (FSIA), 28 U.S.C.A. $§ \S 1604-07$ (2005); See Wolf v. Federal Republic of Germany 95 F.3d 536 ( $7^{\text {th }}$ Cir. 1996) (FSIA protects a foreign nation from jurisdiction in federal and state courts).

${ }^{64}$ Beckman, supra note 11, at 265.

${ }^{65} 28$ U.S.C.A. $\$ 1605$.

${ }^{66} \mathrm{Id}$.

${ }^{67} I d . \S 1605(\mathrm{a})(1)$.

${ }^{68}$ Id. $\$ 1605(\mathrm{a})(2)$.
} 
foreign state; ${ }^{69} 4$ ) in an action in which property rights in the United States are in issue $;^{70}$ ) in an action in which damages are sought for injury, death, or damage to property in the United States caused by the tortious act of the foreign state $;^{71} 6$ ) in an action which is brought to enforce an arbitration agreement or "to confirm an award made pursuant to such an agreement"; $; 2$ or 7) in an action for damages for injury or death resulting from acts of terrorism generally of a foreign state. $^{73}$

Three of these exceptions may arguably allow a United States citizen to bring suit against a foreign nation for injury caused by space debris. ${ }^{74}$ The waiver of immunity provision is the first possible exception. ${ }^{75}$ If a plaintiff could prove the foreign nation waived their immunity in the United States, he or she could proceed. A nation can waive immunity through an explicit provision or implicitly through $\S 1605(a)(1)$. A plaintiff will have more success with an explicit waiver, however, waiver under FSIA is rarely accomplished. ${ }^{76}$ The Supreme Court of the United States has stated that simply entering into an international agreement does not waive immunity. ${ }^{77}$ And it is most unlikely that a foreign nation will voluntarily waive immunity in order to subject itself to an action for a person's injuries sustained while in outer space.

The second possible exception is in $\S 1605(\mathrm{a})(5)$, concerning tortious acts by foreign nations which occur inside the United States. ${ }^{78}$ Unfortunately, the language of the statute indicates that this exception covers only incidents occurring within the territorial jurisdiction of

\footnotetext{
${ }^{69} \mathrm{Id} . \S 1605(\mathrm{a})(3)$.

${ }^{70} I d . \S 1605(\mathrm{a})(4)$.

${ }^{71} 28$ U.S.C.A. $\$ 1605(\mathrm{a})(5)$.

${ }^{72} I d . \$ 1605(\mathrm{a})(6)$.

${ }^{73} I d . \S 1605(\mathrm{a})(7)$.

${ }_{75}^{74}$ Beckman, supra note 11 , at 265-66.

${ }^{75} I d$. at 266.

${ }^{76}$ See Saudi Arabian Airlines Corp. v. Tamimi, 176 F.3d 274, 278 (11 ${ }^{\text {th }}$ Cir. 1999).

${ }^{77}$ Argentine Republic v. Amerada Hess Shipping Corp., 488 U.S. 428, 442 (1989) ("Nor do we see how a foreign state can waive its immunity under $\S 1605(a)(1)$ by signing an international agreement that contains no mention of a waiver of immunity to suit in United States courts ...").

${ }^{78}$ FSIA, 28 U.S.C.A. $§ 1605(\mathrm{a})(5)(2005)$.
} 
the United States. ${ }^{79}$ It seems that $§ 1605(a)(5)$ would "allow recovery for damages suffered as a result of negligent foreign acts within the territorial air space of the United States (for example), but nothing beyond that point" (such as outer space) ${ }^{80}$

The third possible exception, that would subject a foreign nation to the jurisdiction of the United States' courts, is the commercial activity provision. ${ }^{81}$

As it is used in section 1605(a)(2), 'commercial activity' is meant to distinguish activity which results from what in our society would be termed governmental, public or sovereign enterprises e.g., running police departments or parks from those resulting from the acts of foreign state agencies or instrumentalities acting in what we would deem a commercial capacity e.g., operating hotels or cruise ships." ${ }^{82}$

In order to take advantage of this exception, a plaintiff must be able to prove two things: 1) there must be a sufficient nexus between the commercial activity of the foreign nation and the United States, and 2) there must be a substantive nexus between the commercial activity and the cause of action. ${ }^{83}$ Presently, this exception will not aid a United States' plaintiff. It is unlikely that there is a commercial nexus between a foreign nation's space objects and the United States. If the foreign nation has commercial space debris in orbit, such as old commercial satellites, making a connection between the United States and that activity would probably not withstand judicial scrutiny.

This exception may, however, play a greater role in the future. For example, a foreign government may develop a space tourism industry (much like Russia has presently) and recruit United States citizens to travel in space. If one of those citizens were to be injured by space debris connected with the tourist activity, there may be sufficient commercial contacts with the

\footnotetext{
${ }^{79}$ Beckman, supra note 11 , at 268.

${ }^{80} \mathrm{Id}$.

8128 U.S.C.A. $\$ 1605(a)(2)$.

${ }^{82}$ Harris v. VAO Intourist, Moscow, 481 F. Supp. 1056, 1064 (E.D.N.Y. 1979) (citation omitted).

${ }^{83}$ Federal Insurance Co. v. Richard I. Rubin \& Co., Inc., 12 F.3d 1270, 1286 (3d Cir. 1993).
} 
United States and a substantive connection between the commercial activity and the plaintiff's injuries.

In the event that a United States citizen gained jurisdiction over a foreign nation in a damages action for injuries caused by space debris, several additional problems would emerge. One such issue would be a choice of law predicament. As discussed above, the international treaties base liability for injuries occurring in space on a doctrine of fault. ${ }^{84}$ Since this has never been fully defined, it would be difficult to establish a cause of action. There also remains an ongoing debate regarding the use of international common law in United States' courts. ${ }^{85}$ If the courts were to use domestic law, there is a lack of common and statutory law regarding claims which stem from activities in outer space. ${ }^{86}$

Assuming a United States citizen plaintiff could overcome the hurdles of jurisdiction and substantive law, problems regarding settlements and damage awards still remain. In many instances, the United States government has stepped in to prevent settlement of claims or to force the court to vacate a judgment. Following a default judgment against Iran in Roeder v. Islamic Republic of Iran, the United States government stepped in before damages could be awarded. ${ }^{87}$ The government was able to become a party to the suit based on an agreement made following the end of the hostage crisis in 1980, which stated that the United States could prevent prosecution of claims relating to the hostage taking. ${ }^{88}$ The default judgment was vacated and "judgment was entered against the plaintiffs based on the supremacy of the president's right to settle claims through executive agreements .... ${ }^{\prime 89}$ The State Department also intervened in a

\footnotetext{
${ }_{85}^{84}$ Outer Space Treaty, supra note 34, art. VII.

${ }^{85}$ See Genc Trnavci, The Meaning and Scope of the Law of Nations in the Context of the Alien Tort Claims Act and International Law, 26 U. PA. J. INT’L. ECON. L. 193 (2005).

${ }^{86}$ GOLDMAN, supra note 15, at 128 ("The U.S. courts have still not had many opportunities to deal with space law").

${ }^{87}$ Roeder v. Islamic Republic of Iran, 333 F.3d 228 (D.C. Cir. 2003).

${ }^{88}$ Paul J. Kiernan, You Call this a Party? Livening up Your Next Lawsuit, 31 LiTIG. 3 , 34 (2005).

${ }^{89} I d$.
} 
suit by the families of three men killed by the Cuban Air Force when the families tried to collect on a judgment of $\$ 188$ million against Cuba. ${ }^{90}$ More recently, a settlement was reached in a case against Libya for the deaths of United States citizens caused by a terrorist act which resulted in the decedents' plane exploding over Lockerbie, Scotland in $1988 .{ }^{91}$ The money damage award to the private plaintiffs was made contingent upon international diplomatic action. ${ }^{92}$ Congress has vaguely addressed this issue, but only in respect to suits against Cuba and Iran. " "[A] victorious plaintiff who agrees to drop efforts to collect against the foreign government can, in exchange, receive the equivalent of their compensatory damage award from the United States government."94

These examples only open more questions regarding whether a foreign nation will ever have to pay damages for injuries sustained by a United States citizen in outer space. If a plaintiff can surpass the obstacles of jurisdiction over the foreign nation and the court can apply a standard of fault or liability, most likely the United States government would thwart any damage award in the name of diplomatic relations. If Congress decided the United States government would pay the compensatory damages for any foreign country, it still does not address the issue of other types of damages, such as punitive. It seems that whatever the outcome, the foreign nation will never truly be responsible for damage or injury caused by debris they have left in space.

\footnotetext{
${ }^{90}$ Anthony J. Sebok, Libya, Lockerbie, and the Lawyers: What Precedent will be Set by a Possible Pan Am Flight 103 Settlement that also Involves Lifting Sanctions?, Jun. 25, 2002, at http://writ.news.findlaw.com/sebok/20020625.html.

91 Anthony J. Sebok, Libya, Lockerbie and the Long Delayed Settlement, Sept. 8, 2003 at http://writ.news.findlaw.com/sebok/20030908.html.

${ }^{92} I d$. (The settlement agreement is based on the contingency that the United Nations and the United States must drop sanctions against Libya in order for the plaintiffs to collect their damages award).

93 Sebok, supra note 91.

${ }^{94} I d$.
} 


\section{Suits by private United States citizens for damages caused by space debris will not be successful against the United States government.}

Unfortunately, a plaintiff will not have much more success with a suit against the United States government than it will against a foreign nation. A plaintiff is unable to bring suit against their own country for damage caused in outer space under the international treaties. ${ }^{95}$ In addition, a plaintiff would encounter similar problems gaining jurisdiction and applying substantive law against the United States as they would against a foreign nation. ${ }^{96}$

Article VII of the Liability Convention states that a national of a launching state cannot recover under the provisions of the treaty for damage caused by that launching state. ${ }^{97}$ This means that if a United States citizen is injured by space debris caused by the launching of a space object from within the United States, the citizen cannot bring a claim against the United States based on the Liability Convention. The only other option is for the plaintiff to bring suit against the government in the United States. ${ }^{98}$

The United States cannot be sued in domestic courts without its consent. "The Federal Tort Claims Act (FTCA) provides the legislative vehicle through which the United States has consented to be sued for damages caused by its tortious behavior under circumstances in which a private person's similar acts or omissions would trigger liability under local law." ${ }^{, 100}$ Under FTCA, the United States generally waives its sovereign immunity for tort claims, for money damages, injury or loss of property, or personal injury or death, caused by the negligent or wrongful act or omission of any employee of the government while acting within the scope of his

\footnotetext{
${ }^{95}$ Liability Convention, supra note 10 , art. VII.

${ }^{96}$ Beckman, supra note 11; See Bornemann, supra note 11.

${ }^{97}$ Liability Convention, supra note 10, art. VII.

${ }^{98}$ GOLDMAN, supra note 15 , at 81.

${ }^{99}$ United States v. Mitchell, 463 U.S. 206, 212 (1983).

${ }^{100}$ Federal Tort Claims Act (FTCA), 28 U.S.C.A. $§ 1346($ b) (2005); Bornemann, supra note 11, at 517.
} 
employment, under circumstances where the United States, if a private person, would be liable to the claimant in accordance with the law of the place where the act or omission occurred. ${ }^{101}$

As a general proposition, a claim arises under the FTCA where the act of negligence occurred, rather than where the negligence had its effect and caused the damage. ${ }^{102}$ However, location may trigger one of the exceptions to the waiver of sovereign immunity when a claim of negligence arises in a foreign country. ${ }^{103}$ Therefore, if the tort occurs in a foreign nation the United States' judicial system will not have jurisdiction. This exception seems to have been enacted to prevent United States' courts from struggling with interpreting the law of liability of the country in which the tort occurred. ${ }^{104}$ However, where negligence which occurred within the United States was shown to have caused damage outside of the United States, the courts have held that the claim did not arise in a foreign country and was not barred by this exception. ${ }^{105}$ Based on these holdings, space law commentators have posited that FTCA will apply to tort claims brought by citizens who are damaged or injured in outer space by space activities undertaken by the United States government. ${ }^{106}$ These commentators expected the United States judicial system to have jurisdiction over claims brought by private parties against the United States government for injuries sustained in space as the result of space debris.

This presumption has been called into question following the outcome of the Smith case. "In Smith, the Supreme Court had the opportunity to decide whether a region not owned or subject to foreign law (e.g. a region such as outer space) constitutes a 'foreign country' under the

\footnotetext{
10128 U.S.C.A. $\S 1346($ b).

${ }^{102}$ Kurtis A. Kemper, Annotation, What Constitutes, “Claim Arising in a Foreign Country” Under 28 U.S.C.A. $\S$ 2680(k), Excluding Such Claims from Federal Tort Claims Act, 158 A.L.R. FED. 137, 2 (2004).

10328 U.S.C.A. $§ 2680(\mathrm{k})(2005)$.

${ }^{104}$ United States v. Spelar, 338 U.S. 217, 219-20 (1949) (citing Hearings on H.R. 5373 and H.R. 6463 Before the H. Comm.on the Judiciary, 77th Cong., 2d Sess., 35 (1942)).

${ }^{105}$ Kemper, supra note 103 , at 2.

${ }^{106}$ Bornemann, supra note 11 , at 518.
} 
FTCA." 107 If such a territory does constitute a foreign country, it would fall under the exception to waiver of immunity, and any claim brought would be barred.

Mr. Smith was a contracted employee of the National Science Foundation working on a project at McCurdo Station in Antarctica. ${ }^{108}$ Mr. Smith took a hike one day with a fellow worker near the station. On the hike, Mr. Smith fell into an unmarked crevasse and died. ${ }^{109} \mathrm{Mr}$. Smith's widow filed a wrongful death action under the FTCA in the United States District Court for the District of Oregon claiming that United States employees had failed to properly warn her husband of dangerous crevasses along the marked hiking paths. ${ }^{110}$

The Smith case was appealed to the Supreme Court on the issue of jurisdiction. ${ }^{111}$ The Court focused on the issue of whether Antarctica is considered a foreign country under the exception to waiver of immunity under the FTCA. ${ }^{112}$ An inquiry into the definition of "country" wielded "[a] region or tract of land." 113 The Court opined that the ordinary meaning of the word country included Antarctica, even though it has no recognized government. ${ }^{114}$ They found that Antarctica is definitely excluded from the Act because to find otherwise the ttatute "would instruct courts to look to the law of a place that has no law in order to determine the liability of the United States - surely a bizarre result." ${ }^{\prime 15}$ Therefore, Antarctica is considered a foreign country under the exceptions to the FTCA and the United States judicial system does not have jurisdiction over the United States government for torts which occur there.

\footnotetext{
${ }^{107}$ Beckman, supra note 11 , at 259.

${ }^{108}$ Smith v. United States, 507 U.S. 197, 199 (1993).

${ }^{109} \mathrm{Id}$.

${ }^{110} \mathrm{Id}$.

${ }^{111}$ Id. at 197.

${ }^{112} \mathrm{Id}$. at $199-200$.

${ }^{113} \mathrm{Id}$. at 201.

${ }^{114}$ Smith v. United States, 507 U.S. 197, 201 (1993).

${ }^{115} \mathrm{Id}$. at 201-02.
} 
The reasoning employed in the Smith opinion does not leave a welcome door open for plaintiffs that have been injured by the activities of the United States government in outer space. "If a place need only be a 'region or tract of land' outside of United States territory to be a 'foreign country,' outer space is certainly a foreign country." "116 "[Outer] space has no more law of its own for choice of law purpose than does Antarctica."117 "If the Court believes that the FTCA is governed by the presumption against extraterritoriality, then surely it believes it subject to a presumption against extraterrestriality."

\section{Recent space legislation shields the United States government from liability for loss due to space debris through waiver provisions.}

In an effort to stimulate private sector space activities, the government passed the

Commercial Space Launch Activities Act (CSLA) and amendments. ${ }^{119}$ Although suit against the United States government would most likely be unsuccessful, the government has managed to shift the burden of compensating individuals for injury caused by government space debris to private companies, through the CSLA. ${ }^{120}$

The CSLA manifests Congress' efforts to facilitate the growth of the U.S. private space launch industry. ${ }^{121}$ It was enacted to encourage private industries to participate in space activities. ${ }^{122}$ However, in the interests of safety, the federal government maintains regulatory authority over private entities wishing to participate in any space launch activities. ${ }^{123}$ Each entity

\footnotetext{
116 Bornemann, supra note 11 , at 535.

${ }^{117} \mathrm{Id}$.

${ }^{118} \mathrm{Id}$.

${ }_{119}$ Commercial Space Launch Activities Act (CSLA), 49 U.S.C.A. $§ 70101$ et. seq. (Supp. 2006).

${ }^{120} 49$ U.S.C.A. $§ 70112$.

${ }^{121} 49$ U.S.C.A. \$ 70101; Kim B. Watson, Article, Have the Courts Grounded the Space Launch Industry? Reciprocal Waivers and the Commercial Space Launch Act, 39 JURIMETRICS J. 45 (1998).

12249 U.S.C.A. $\$ 70101$.

${ }^{123}$ Id. $\S \S 70103-104$.
} 
must obtain a license from the United States government. ${ }^{124}$ The Secretary of Transportation reserves the right to prescribe any terms or requirements for these licensees. ${ }^{125}$

One of the provisions enacted is the reciprocal waiver of claims. ${ }^{126}$ Under this section, any private licensee makes a reciprocal waiver of claims with any government entity or agency, which is involved with the licensee's space launch activities, for any injury to or death of any space flight participants of the licensee, resulting from an activity carried out under the applicable license. ${ }^{127}$ This means that the private licensee agrees to be liable to any space flight participant regardless of the government's involvement. This provision remains important in the beginning stages of the private space industry. Historically, the government has been the main body that has instigated any space launch or space travel activities in the United States. Private sector space licensees will most likely initially work with government agencies that have the existing infrastructure and resources to promote space travel. There is great likelihood that a government entity will somehow be involved in any given private space launch activity. The reciprocal waiver of claims provision would protect any government agency that is working with the private licensee.

This does not bode well for private space tourists on flights of a licensee. If a tourist is injured in space while on a licensee space launch, even if the injury is the result of space debris left by the government, the government will be relieved of liability. The responsibility will remain in the hands of the licensee. The CSLA comes into play for any injury resulting from "activity carried out under the applicable license."128 A common sense reading of the statute seems to imply that liability should be waived only for injuries that are a direct result of the

\footnotetext{
12449 U.S.C.A. $\S 70104$.

${ }^{125}$ Id. $\S 70105$.

${ }^{126}$ Id. $\S 70112(\mathrm{~b})$.

${ }^{127}$ Id. $\S 70112(\mathrm{~b})(2)$.

128 Id.
} 
licensee's launch, and not risks such as runaway space debris. However, a strict reading of the law does not specify how the injury occurs, just that it be a result of the launch activity. ${ }^{129}$ Under this reasoning, the government may leave dangerous debris in space, aid a licensee launch private citizens into space, and then remain immune from liability for any injury which occurs on that flight caused by their debris.

A private space tourist may gain some comfort from another provision of the CSLA that requires licensees to carry liability insurance. ${ }^{130}$ The CSLA requires launch licensees to obtain liability insurance to compensate for claims by "third parties" for death, injury or property loss or damage as a result of space activity carried out under the license. ${ }^{131}$ Unfortunately, the statute specifically excludes space flight participants from classification as a "third party." government does not require that the private licensee carry liability coverage for private space participants such as space tourists. Most likely, the licensee will have a private agreement between all space flight participants that may or may not waive liability on the part of the licensee. But, the private space tourist cannot rely on the liability insurance provision of the CSLA to compensate them for loss caused by space debris.

\section{Conclusion}

As private space travel becomes less a dream of the future and more a summer vacation plan, international and domestic law needs to evolve to accommodate the needs of the industry. A consistent remedy available to those injured in space is a necessity. The dangers posed by space debris, almost wholly the result of government space activities, represent a real risk to

\footnotetext{
${ }^{129} I d$.

${ }^{130} 49$ U.S.C.A. § 70112(a).

${ }^{131} I d$. $\S 70112(\mathrm{a})(1)$-(3) (requires a maximum of $\$ 500,000,000$ in liability insurance to compensate for claims by third parties and a maximum of $\$ 100,000,000$ in insurance to compensate for claims by the United States Government).

${ }^{132}$ Id. $\S 70102(21)(\mathrm{E})$.
} 
space flight participants. These participants must have a forum in which to bring claims for loss and the means to hold a responsible party liable.

One method, albeit a difficult one, would be to amend international law or propose new law that specifically defines the types of objects that are considered debris and when a member to a treaty is at fault for the debris. Although the complexities of political negotiation between member states may remain, the clear outline of fault would perhaps place pressure on member nations to come to some type of diplomatic agreement regarding compensating space flight participants for losses sustained in space.

Domestic law must be revised, especially the FTCA, to allow United States' courts to have jurisdiction over claims which occur in outer space. If the purpose of FTCA is to prevent the United States' courts from interpreting foreign law, it would seem to follow that claims which arise in "lawless" locations, such as space, would not be excluded from the United States' judicial system, especially if the government is a party to the claim.

If the purpose of the CSLA is truly to encourage private space enterprise, it must reflect willingness by the government to remain liable for damage or loss caused by its space debris. The reciprocal waiver of claims provision should include injuries that are caused only as a direct result of the private licensee's activities, not as a result of activities out of its control, such as the prior accumulation of space debris.

In order to ensure the continuing success of the private space industry in the United States, space flight participants need to feel comfortable taking part in a launch. If they are aware that it is very difficult to hold governments liable for any injuries which they may suffer at the hands of left over government space garbage, they may be reluctant to take a flight. Private space businesses that cannot attract passengers will most definitely fail. The most logical 
conclusion is to protect private space flight participants and not leave injured passengers out floating in space without redress. 